which was found to vary almost linearly with added acid or alkali.

$0.1 \mathrm{~mol}$. of each of the following was dissolved separately in $250 \mathrm{ml}$. water, the solutions being mixed in the order shown just prior to use: sodium carbonate, 2-amino-2-methyl propan-1 : 3-diol ${ }^{3}$ (Eastman-Kodak reagent); sodium dihydrogen orthophosphate; citric acid.

Van Slyke ${ }^{4}$ and Britton and Robinson ${ }^{2}$ deduce that in mixtures of buffer substances a constant buffering power over the working $p \mathrm{H}$ range will be obtained if the consecutive $p K$ values of the acids involved differ by not more than $1 \cdot 2$. In the present system the $p K$ values are deduced to $b e^{3,5}$ :

$1 \cdot 0 ; 3 \cdot 1: 4 \cdot 7: 5 \cdot 4: 6 \cdot 4: 7 \cdot 1 ; 8 \cdot 8 ; 10.4$ and $12 \cdot 3$.

These approximate to the ideal system, and the buffering power in fact remains nearly constant between $p \mathrm{H} 2$ and 12 (Fig. 1).

\section{A. ELLIS*}

\section{Department of Biochemistry,} University of Leeds.

* Present address: Midland Centre for Neurosurgery, Holly Lane, Smethwick, Staffs.

${ }^{1}$ Prideaux, E. B. R., and Ward, A. T., J. Chem. Soe., 125, 426 (1924),

${ }^{2}$ Britton, H. T. S., and Robinson, R. A., J. Chem. Soc., 1457 (1931).

${ }^{3}$ Gomori, G., Proc. Soc. Exp. Biol. Med., 62, 33 (1946)

4 Van Slyke, D. D., J. Biol. Chem., 52, 558 (1922).

${ }^{5}$ Handbook of Chemistry and Physics, thirty-second ed., 1507 (Chemical Rubber Pub. Co., Cleveland, Ohio, 1950).

\section{RADIOBIOLOGY}

\section{Determination of Cæesium-137/Potassium Ratios in Diet and in the Human Body by Urine Analysis}

A RADIOCHEMical method ${ }^{1}$ has been developed for the determination of cæsium-137 in urine. Acidified urine containing cæsium carrier is passed through a column of ammonium phosphomolybdate mixed with an equal weight of asbestos to give adequate porosity. The ammonium phosphomolybdate acts as a highly selective cation-exchanger and retains the cæsium quantitatively, even at comparatively high flow-rates. Other cations, including sodium, potassium and the alkaline earths, are not retained to any significant extent. After all the sample has passed through the column, the ammonium phosphomolybdate is dissolved in sodium hydroxide solution and the cæsium precipitated as the cobaltinitrite. The removal of final traces of potassium and rubidium from the cæsium is onsured by its subsequent precipitation as the bismuth iodide complex and finally as the chloroplatinate, which is filtered, dried and beta-rays counted. The recovery of carrier normally exceeds 80 per cent. The sensitivity of this method makes it particularly useful for the determination of fall-out crsium-137 in urine, as current concentrations are low and are likely to decline still further.

The cæsium-137 contents of seven urine samples collected in February, March and April 1961 were determined by this method. These samples were prepared by bulking at least 10 specimens obtained from individuals, mostly resident in Berkshire, with no known exposure to cresium-137 other than fall-out levels in their diet. Potassium was estimated in the same samples by flame photometry. The results of these analyses are given in Table 1.
Table 1. Casidm-137 and Potassiom Gongentrations in BULKeD

$\begin{array}{cccc}\begin{array}{c}\text { Date of } \\ \text { collection }\end{array} & \begin{array}{c}\text { URINE SAMPLES } \\ \text { Casium-137 } \\ (\mu \mu \mathrm{c} . / 1 \text {. })\end{array} & \begin{array}{c}\text { Potassium } \\ \text { (gm./1.) }\end{array} & \begin{array}{c}\text { Ratio } \\ (\mu \mu \mathrm{c} . / \mathrm{gm} .)\end{array} \\ 21.2 .61 & 29 \cdot 9 & 2 \cdot 47 & 12 \cdot 1 \\ 1.3 .61 & 21 \cdot 1 & 2 \cdot 00 & 10 \cdot 6 \\ 7.3 .61 & 26 \cdot 8 & 2 \cdot 73 & 9 \cdot 8 \\ 14.61 & 24 \cdot 3 & 1 \cdot 73 & 14 \cdot 0 \\ 20.3 .61 & 24 \cdot 6 & 1 \cdot 66 & 14 \cdot 8 \\ 10.4 .61 & 26 \cdot 2 & 2 \cdot 07 & 12 \cdot 7 \\ 28.4 .61 & 21 \cdot 7 & 2 \cdot 07 & \text { Mean } 12 \cdot 1\end{array}$

In vivo cæsium-137/potassium ratios were determined by Rundo, J. (private communication, 1961) in 14 residents of Oxfordshire and Berkshire during March 1961. The mean value for this group was $36 \mu \mu c . / g m$., which is almost exactly three times the value for this ratio in urine given in Table 1. Values for the ratio :

$$
\frac{\text { cæsium }-137 / \text { potassium in the body }}{\text { cæsium-137/potassium in urine }}
$$

have also been determined for a number of individuals by Rundo and by Miller and Marinelli2. These varied from 1.9 to $4 \cdot 6$, indicating that individuals may show a considerable departure from the average value of $\mathbf{3}$ obtained in the present comparison.

As both cresium and potassium are completely absorbed from the human gastro-intestinal tract, the casium-137/potassium ratio in urine will be equal to that in the diet and should also be one-third of that in the body, under equilibrium or near equilibrium conditions. This is in agreement with the measurements of McNeill and Trojan ${ }^{3}$, who measured the cæsium-137/potassium ratio in the diet of Toronto residents and in the residents themselves, using a $\gamma$-spectrometric technique. They found that the body/ diet ratio was $3: 1$.

The analysis of bulked urine samples appears to provide a simple method for assessing current cresium-137/potassium ratios in both diet and the human body, so long as dietary-levels are not changing too rapidly. By analysing a bulked sample, the difficulty in selecting representative aliquots of various items of diet for analysis is avoided.

The possibility of monitoring strontium-90 in diet by urine analysis has been proposed by Schulert", whose measurements show that the strontium-90/ calcium ratio in diet is approximately twice that in the urine. Both strontium-90 and cæsium-137 may be estimated on the same sample by adding strontium and cæsium carrier to urine before passing it through the ammonium phosphomolybdate column. While cæsium is retained on the column, both strontium and calcium pass through and may be co-precipitated from the effluent as the oxalates. Separation of the strontium from the calcium and determination of the strontium- 90 can then be effected by well-established techniques.

We wish to thank Mr. W. H. A. Raymond of the Medical Research Council Radiobiological Unit, Harwell, who carried out potassium determinations in the urine samples.

\section{A. Morgan \\ GLORIA M. ARKETI}

Atomic Energy Research Establishment, Harwell,

Didcot.

${ }^{1}$ Arkell, G. M., and Morgan, A., Atom. Energy Res. Est., Harwell, R. 3675 (1961).

${ }^{2}$ Miller, C. E., and Marinelli, L. D., Argonne Nat. Lab. Rep. ANL-5919, 74 (1958).

${ }^{3}$ MeNeill, K. G., and Trojan, O. A. D., Health Phys., 4, 109 (1960).

- Schulert, A. R., Nature, 189, 933 (1961). 